\title{
FROM NEO-OTTOMANISM TO ERDOGANISM: A DOCTRINE AND FOREIGN POLICY OF TURKEY
}

\section{Darko Tanasković}

Association of Non-Governmental Organisations of Southeast Europe CIVIS, Beograd, 2016.

DOI: 10.20901/an.15.15

Ne bi bilo teško braniti tvrdnju kako je od svih država euroazijskog područja u posljednjih dvadesetak godina Turska doživjela najdublju i najopsežniju transformaciju. Neke promjene kroz koje je ta država prošla bez presedana su čak i na turbulentnome Bliskom istoku. Istina, nasuprot drugima bliskoistočnim državama pogođenima velikim prevratima i promjenama, iz Turske su rijetko stizale vijesti o dramatičnim zbivanjima i iznenadnim preokretima. Stjecao se dojam da prema opsegu i dubini transformacije prednjače ratom zahvaćeni Siriju, Irak i Jemen, pa i neke europske zemlje poput Mađarske, Njemačke ili Švedske, u kojima populistični pokreti iz temelja mijenjaju politički krajolik društva. No dojam vara.

Transformacija kroz koju je posljednjih desetljeća prošla Republika Turska tema je knjige Darka Tanaskovića Od neoosmanizma do erdoganizma: doktrina $i$ vanjska politika Turske. Tanasković, ugledni beogradski profesor, znanstvenik i orijentalist rođen u Zagrebu, donedavno je bio veleposlanik Srbije u UNESCO-u u Parizu, a prije toga bio je veleposlanik u Turskoj i Vatikanu. Veći dio znanstvene karijere proveo je kao profesor na Katedri za orijentalistiku na Filološkom fakultetu u Beogradu te je još od vremena bivše države slovio kao jedan od najvećih autoriteta za islamologiju. Objavio je brojne znanstvene radove i nekoliko knjiga o Turskoj. Kvaliteti Tanaskovićevih tekstova značajno pridonosi njegovo znanje turskoga i arapskog jezika; te jezike, kao i tursku i arapsku književnost, predavao je na Filološkom fakultetu. Djelo koje je predmet ove recenzije također upućuje i na tekstove na turskom jeziku.

Knjiga Od neoosmanizma do erdoganizma podijeljena je na osam poglavlja: (1) Neoosmanizam ili erdoganizam? (2) Suočavanje s izazovima trećeg tisućljeća. (3) Definicija i glavne značajke neoosmanizma. (4) Stupnjevi razvoja pojma neoosmanizma. (5) Geopolitika "strateške dubine". (6) Globalne koordinate neoosmanizma. (7) Regionalni aspekti neoosmanizma. (8) Zaključak. Na kraju knjige nalazi se pogovor "Arapsko proljeće, turska jesen" u kojemu autor rekapitulira fenomen neoosmanizma i osvrće se na promjene i dinamiku u interakciji Turske i bliskoistočnih država u kontekstu "Arapskog proljeća", a osobito rata u Iraku i Siriji.

U napomenama u uvodnom poglavlju navedeno je da je prvo izdanje ove knjige objavljeno na srpskom jeziku 2010, a prvo izdanje na engleskom jeziku, koje je publicirano 2013, prijevod je drugoga srpskog izdanja iz 2011. Izdanje na engleskom jeziku nastalo je nakon nekih ključnih zbivanja u Turskoj, poglavito ostavke premijera Ahmeta Davutoğlua u svibnju 2016. i pokušaja vojnog uda- 
ra u srpnju te godine. Od prvoga (2010) do posljednjeg izdanja (2016) značajno se promijenila percepcija pojma neoosmanizam koji je uvelike prestao biti kontroverznim: "...Mnogi su analitičari i stručnjaci smatrali 2010. da je uporaba pojma neoosmanizam neopravdana, a u Turskoj je on uglavnom odbacivan kao neprikladna ideološka optužba. Mnogo se toga promijenilo do danas. Premda o neoosmanizmu postoji niz stavova, općenito je prepoznato kako je riječ o najtočnijem opisu doktrine na kojoj se temelji turska vanjska politika..." (str. 5). Autor na početku knjige napominje da nije kanio kronološki prikazati unutarnju i vanjsku politiku Turske. Od čitatelja se očekuje da ima osnovno znanje o povijesti Osmanskog Carstva i Republike Turske, kao i o ključnima političkima procesima koji su Republiku Tursku obilježili od njezina nastanka do danas. ${ }^{1}$ Čitatelj će u knjizi Od neoosmanizma do erdoganizma: doktrina $i$ vanjska politika Turske otkriti kako se, kroz stvarnu ili imaginarnu interakciju prošlosti i sadašnjosti pod žezlom jednoga ambicioznoga, strpljivog i beskrupuloznog vizionara, stvarao državni akter čija će uloga na svjetskoj političkoj pozornici jačati još godinama. Neoosmanizam autor definira kao "složenu makroideološku platformu sukladno kojoj današnja Turska, kao legitimna civilizacijska baštinica Osmanskog Carstva, reafirmira cijelu svoju duhovnu, kulturnu i političku stečevinu kako bi osigurala i učinkovito nastupila u ulozi globalne sile koju $\mathrm{u}$ aktualnim preslagivanjima ravnoteže snaga i utjecaja u svijetu svakako valja uzeti u obzir" (str. 16).

Najvažnija sfera očitovanja neoosmanizma, kao što najavljuje podnaslov,

\footnotetext{
1 Kvalitetan uvid u povijest, politiku i institucije Turske na hrvatskom jeziku nudi poglavlje "Turska" Dejana Jovića u zborniku: Kasapović, Mirjana. (ur.). 2016. Bliski istok: politika i povijest. Zagreb: Fakultet političkih znanosti.
}

jest turska vanjska politika. U najvećem dijelu svoje knjige Tanasković analizira interakcije turske neoosmanske politike s politikama važnih međunarodnih državnih aktera, kakvi su Sjedinjene Države, Rusija i Kina, Europska unija te područja Kavkaza, Bliskog istoka i Balkana. Većina tih analiza može se smatrati uvodnima. Nijedna nije previše opsežna i sveobuhvatna, ali u svakoj su prikazani ključni suvremeni procesi koji nerijetko nisu postojali prije devedesetih godina 20. stoljeća. Autor adresira promjene u turskoj vanjskoj politici, kao i promjene koje se neovisno o Turskoj zbivaju u tim zemljama i područjima. Sve to čini interakciju iznimno složenom, bez mnogo konstanta i sa stalnima preobrazbama. Tanasković se, osim konkretnih primjera, usredotočio na načela i trendove koji se, premda možda u drugačijem obliku ili s novim pročeljem, mogu očekivati i u bližoj budućnosti. Tako u dijelu u kojemu opisuje odnose Turske i Europske unije piše: "Postupna (re)islamizacija turskog društva počela je sve više zabrinjavati, premda su europski i američki zagovornici turske kandidature (za članstvo u Europskoj uniji, nap. B. H.) opetovano ponavljali kako je riječ samo o 'umjerenom islamu' koji je kompatibilan s demokracijom i europskim vrijednostima" (str. 71).

Osvrće se i na "licemjerno" postupanje prema Turskoj, budući da Europska unija "nikad nije otvoreno rekla kako je glavna zapreka turskom pristupanju Uniji to što je Turska muslimanska država s tako brojnim stanovništvom" (str. 71). Potom tvrdi kako postoji "obilje pokazatelja" da "islamisti/neoosmanisti nemaju iskrenu želju pristupiti EU..." (str. 73). Taj je stav argumentiran time što u Uniji Turska ne može steći položaj središnje i najvažnije države, kao što vjeruje da može drugdje. K tome, jasno je i to da Turska svoje zakonodavstvo neće potčiniti Acquisu. Odnosi s Europskom uni- 
jom stoga su u neoosmanskom preslagivanju važni poglavito u gospodarskome i trgovinskom kontekstu, ali je ključna vanjskopolitička ambicija Erdoğanova režima usmjerena na druga područja.

Erdoğan je u vanjskoj politici napravio najvidljiviji otklon od ostavštine utemeljitelja moderne Turske. Atatürkova Turska povukla se iz međunarodnih zbivanja, uključujući i zbivanja na područjima kojima je donedavno gospodarila, te se usredotočila na izgradnju snažne nacionalne države. To se, primjerice, očitovalo u turskoj neutralnosti u Drugome svjetskom ratu. I kasnija turska vanjska politika, unatoč obvezama koje je donijelo članstvo u NATO-u, nije značajnije odstupala od te doktrine; dapače, Turska je katkad postupala sukladno interesima, primjerice, Sjedinjenih Država, a nauštrb vlastitih interesa. Promjene turske politike od primarne usredotočenosti na unutarnje procese $\mathrm{k}$ težnji da opet postane neizbježan akter u vanjskopolitičkim procesima regije jedan je od ključnih čimbenika neoosmanizma. $\mathrm{K}$ tomu, neoosmanizam ne želi ništa manje od liderske pozicije Turske u onome međunarodnom opsegu u kojem je to moguće, a on se načelno poklapa s granicama nekadašnjega Osmanskog Carstva. U tom kontekstu Tanasković implicira da interes Turske nije priključivanje Balkana Europskoj uniji nego ostanak pred njezinim vratima. $\mathrm{Na}$ taj način Balkan biva "ostavljen s Turskom $\mathrm{i}$ ostavljen Turskoj" kako bi ponovno postao "osmanska Rumelija" (str. 97).

Polazna točka neoosmanizma u vanjskoj politici bilo je nastojanje Turske da postigne "nultu razinu sukoba sa susjedima". Autor objašnjava kako je tekao proces zbližavanja Turske sa susjednim državama, posebno s područjima Kavkaza, Bliskog istoka i Balkana. U odnosima Turske s Iranom, Irakom i Sirijom prikazani su najvažniji procesi, koji su nakon "Arapskog proljeća" postali nepostojanima i krajnje složenima. U iznenadnima političkim obratima koji su zaredali Bliskim istokom nakon 2012. Turska je često morala iznalaziti ad hoc rješenja, a politiku neoosmanizma, koja je dugoročna, primjenjivala se konfuzno i nedosljedno. Takvima se mogu okarakterizirati i turski odnosi s bliskoistočnim susjedima. Oni se mogu sažeti u kritici neoosmanizma u vrijeme premijerskog mandata Davutoğlua koji je tursku politiku uspio skrenuti s politike "nulte razine sukoba sa susjedima" prema politici "nulte razine prijateljstva među susjedima". Tim je odnosima posvećen pogovor (str. 117-143) koji čini zasebnu cjelinu. U knjizi nedostaje osvrt na utjecaj neoosmanizma na tursko-izraelske odnose; zapravo iznenađuje što se autor nije podrobnije osvrnuo na njih, budući da se iz drugih njegovih tekstova vidi da ih vrlo dobro poznaje.

Nije nimalo neočekivano što najveću pozornost i najviše prostora u knjizi (str. 92-112) autor posvećuje Balkanu. Ključne saveznike na Balkanu Turska vidi u muslimanima, poglavito Bošnjacima. Za utjecaj među balkanskim muslimanima Turska se još od devedesetih godina bori s Iranom i Saudijskom Arabijom, odnosno sa šijitskom i vehabitskom inačicom islama koje su strane osmanskoj tradiciji. No neoosmanska se ambicija ne ograničava samo na izgradnju savezništva $s$ balkanskim istovjercima. Važna komponenta neoosmanizma, uz religiju, jest mit - mit kako je Osmansko Carstvo svim svojim podanicima omogućavalo gospodarski i kulturni napredak pa bi, prema toj logici, obnova osmanskog poretka u nekom obliku blagotvorno utjecala i na nemuslimansko stanovništvo. Stoga su veliku popularnost u Turskoj stekle teze Marije Todorove o Balkanu iz kojih se izvodi tvrdnja kako Osmansko Carstvo nije bilo "klasičan kolonijalni imperij", pa se ni oslobođenje naroda od osmanske vladavine ne može smatrati 
dekolonizacijom. Tanasković pak ukazuje na to da Todorova u svojoj knjizi ne postavlja pitanje oslobodilačkog karaktera $\mathrm{i}$ ishoda borbe potčinjenih naroda (str. 99). Ambicijom da uz islam, koji nedvojbeno čini snažnu poveznicu između Turske i balkanskih muslimana, $\mathrm{u}$ osmišljavanje politike na Balkanu uključi i mitove - a teško je zamisliti da u njih vjeruju i sami neoosmanisti - Turska se zapleće u složene i nerješive teškoće. Tanasković se u analizi neoosmanizma uvelike oslanja na knjigu Strateška $d u$ bina nekadašnjega visokog dužnosnika vladajuće Stranke pravde i razvoja (AKP), ministra vanjskih poslova i premijera Ahmet Davutoğlua, te uočava da na više od pet stotina stranica knjige Davutoğlu nije artikulirao politiku samo prema dvjema balkanskim državama kojima je Osmansko Carstvo vladalo: Grčkoj i Srbiji. Potom zaključuje: "Jasno je kako se u strateškom smislu na te dvije države još uvijek gleda kao na čimbenike protiv kojih će se implementirati, a ne $s$ kojima će se implementirati turska politika, čak i u kontekstu neminovne bilateralne suradnje" (str. 108). Ipak, Turska je uvijek prepoznavala važnost Srbije pa autor postavlja pitanje koliko je Turska spremna napraviti iskorak kako bi sa Srbijom izgradila partnerstvo utemeljeno na jednakosti i bez "fige u džepu". Zaključno tvrdi kako je partnerske odnose Turske sa Srbijom, Grčkom, a djelomice i s Bugarskom "teško pomiriti sa samom biti neoosmanizma" (str. 109). Premda to partnerstvo ne treba odbaciti kao potpuno nemoguće, ono "trenutačno nije odveć izgledno" (str. 109).

Odnos Erdoğanove Turske prema okolnim državama i područjima obilježuje vanjska politika koja je "istodobno ideološka, kulturološka, ekonomska i politička" (str. 16). Na putu provedbi te politike dugo je stajala, a još uvijek nije posve uklonjena, činjenica da ona znači korjenito odstupanje od načela kemaliz- ma. Budući da se neoosmanizam temelji na "oživljavanju osmanske duhovne i kulturne baštine" (str. 17), on poglavito odstupa od kemalističkoga načela sekularne nacionalne države i znači povratak islamu kao temeljnoj odrednici identiteta i politike. Autor višekratno ističe kako je "neoosmanizam neraskidivo povezan s islamizmom" (str. 18) pa se na trenutke gotovo stječe dojam da ih smatra istoznačnicama (str. 73). No nije tako: "Islamizam čini neraskidiv dio neoosmanizma, ali se ne može svesti na njega" (str. 126). Uloga je islama u transformaciji turskoga društva i politike pod Erdoğanom presudna, pa je takav autorov pristup opravdan čak i ondje gdje je ta veza naizgled prenaglašena. Mnoštvo analiza turske politike proizveli su autori koji su uložili mnogo kreativnosti kako bi izbjegli isticanje pa i samo spominjanje islamske vjere, što je usiljen, znanstveno neopravdan i ideološki opterećen pothvat. No u skladu je s onime što je Erdoğan želio postići poslije osnutka AKP-a, a to je islamizacija politike i društva bez izravnog referiranja na islam: "Islamski je aspekt (političkog programa AKP-a, nap. B. H.) eufemistično opisivan kao tradicionalni 'sustav vrijednosti svojstven našoj povijesti'" (str. 125). Eufemizmi kojima je priroda Erdoğanove politike dugo zamagljivana pred europskim političarima $\mathrm{i}$ analitičarima nisu novost i nisu Erdoğanov izum. Dijelovi islamskog svijeta u interakciji sa Zapadom dugo se već oslanjaju na njih, osobito otkako su zaslugom Edwarda Saida zapadna sveučilišta abdicirala pred optužbama za kolonijalne ambicije i prijezir prema islamskim zemljama i kulturi te odustala od znanstvenog izučavanja islama.

No eufemizmi i saidovski diskurs nikada nisu zavarali Tanaskovića. ${ }^{2}$ Upravo zbog analiza turske politike u kojima su

2 Vidi, primjerice, Tanasković, Darko. 2006. Islam i mi. Beograd: Partenon. 
Erdoğanovi eufemizmi polučili željeni rezultat, Tanaskovićev pristup toj temi pravo je osvježenje. On, s jedne strane, ne izbjegava tematiziranje uloge islama u Erdoğanovoj unutarnjoj i vanjskoj politici, koju će dio čitatelja smatrati kontroverznom i "hantingtonovskom", ali toj temi, s druge strane, pristupa bez strastvenog zauzimanja strane, moraliziranja, vrednovanja - "Neoosmanizam", kaže autor, "sam po sebi nije ni dobar ni loš" (str. 116) - ili panike, što bi pak drugi čitatelji od njega možda očekivali. Tanasković definira neoosmanizam kao "ideološki amalgam islamizma, turkizma i osmanskoga imperijalizma" (str. 26), odnosno kao fenomen "koji učinkovito objedinjuje tri stupa ideologije, islamizam, nacionalizam i imperijalnu nostalgiju, pri čemu nijedna ne prevladava nad drugima dvjema" (str. 125-126). Na drugome mjestu piše kako je neoosmanizam po svojoj prirodi sinkretičan (str. 83; na str. 112 taj pridjev koristi uz osmanizam). To je važno opažanje pa bi tu sinkretičnost bilo korisno razložiti. Tradicionalna nespojivost islama s nacionalnima, imperijalnim i naslijeđenim identitetima, odnosno koncept asabijaha, nije širem čitateljstvu poznat. Sustav koji je iznjedrilo Erdoğanovo političko djelovanje jedinstven je u dosadašnjoj povijesti islamskoga svijeta i može se opisati kao nacionalni islamizam, a taj bi pojam prije Erdoğanovih reforma bio nezamisliv i predstavljao bi oksimoron. Dubljim uvidom $u$ postulate političkog islama postaje jasnim koliko je neoosmanizam zapravo hibridna, eklektična, odnosno "sinkretična" pojava. Šira bi javnost imala velike koristi od podrobnijega objašnjenja neobičnosti i jedinstvenosti toga fenomena iz perspektive islamske tradicije i teologije te bi to svakako trebalo uvrstiti u eventualnu novu i opsežniju studiju neoosmanizma.

Upravo je eufemistična i sinkretična sastavnica Erdoğanove transformacije
Turske zaslužna za relativno neupadljiv, gotovo puzeći način na koji se zbila transformacija Turske. Erdoğanovi prethodnici, koji su u tursku politiku pokušali vratiti elemente islama što ih je Atatürk iz nje izbacio nakon propasti Osmanskoga Carstva i uspostave Republike Turske, doživjeli su neuspjeh za koji se, sukladno ustavnim ovlastima, pobrinula vojska. Erdoğan je tu lekciju dobro naučio. Zato se skretanje ka islamizmu pod njegovom vladarskom palicom nije odvijalo poglavito kroz drske, prevratničke i osobito nagle poteze. Ono je, kolikogod je to bilo moguće, provedeno kroz institucije države, a ne u srazu s njima. Tanasković izvanredno uočava i opisuje taj proces: sekularizam je podrivan "odozdo prema gore..., poglavito u sferi religijskog obrazovanja" (str. 30). Upravo zbog toga postoji uvodno spomenuti nerazmjer između dubine i opsega promjene Turske pod Erdoğanom i općeg dojma o dubini i opsegu te promjene u europskoj i svjetskoj javnosti.

Tanasković piše kako se početak reislamizacije turskoga društva i udaljavanja od kemalizma može izravno povezati s uvođenjem demokratskoga višestranačkog sustava 1946. pod pritiskom Zapada. "Paradoks, koji se zasniva na činjenici kako je logično očekivati da prozapadnjačko i proislamsko opredjeljenje budu međusobno suprotstavljeni, samo je prividan" (str. 27). Nakon te smione izjave slijedi objašnjenje primjenjivo na današnju Tursku, ali i na bliskoistočne države zahvaćene "Arapskim proljećem", koje je logično, dokazivo i dokazano, ali i uvelike problematično, pa ga većina autora koje poznajem odbacuje ili od njega okreće glavu kao da se nada da će nestati ako se bude dovoljno ustrajno zanemarivalo: "Kako se kasnije tijekom vremena pokazalo, demokracija propisana zapadnjačkim standardima u muslimanskim zemljama prije ili kasnije vodi k zakonitu usponu na vlast (pro) 
islamističkih stranaka, budući da je u svim tim zemljama, uključujući i ustavno laičku i vrlo sekulariziranu Tursku, islam zadržao položaj kamena temeljca osobnoga i kolektivnog identiteta, te da se na njemu zasnivaju duboko ukorijenjeni sustav vrijednosti i smjernice za društvenu interakciju u običnom puku. Sekularan se sustav može održati isključivo putem nekog oblika diktature, pod krinkom oponašanja demokratske parlamentarne procedure" (str. 27).

Veliku vrijednost Tanaskovićeva djela čini objektivno i nesputano adresiranje osjetljivih tema kao što je ova, kao i uloga religije i mitologije u stvaranju nove turske politike i imidža. No autor ne pretjeruje u pridavanju važnosti tim temama. Osvrti na ekonomiju, pragmatične odnose s Europskom unijom, medije, unutarstranačka previranja ili sukobe s kurdskom nacionalnom manjinom popunjavaju sliku tako da se složenost fenomena neoosmanizma ni $\mathrm{u}$ jednom trenutku ne stavlja pod upit niti se taj fenomen simplificira. Ništa u ovoj knjizi nije izneseno površno. Svaka je osjetljiva misao pomno odvagnuta, a tek je pokoja iznesena tako da se najbolje iščitava uz pomoć lokalnih civilizacijskih kodova. Osjećaj za političku i sigurnosnu relevantnost teme u cijeloj knjizi prati osjećaj dugoročne odgovornosti za napisanu riječ, a opet se ne stječe dojam da je knjiga pisana "u rukavicama," ambigvitetno, nejasno, a kamoli neiskreno. Iz cijelog teksta iščitavaju se nenametljivo, a istodobno dojmljivo autorovo opsežno znanje, pronicljivost i odmjerenost, te iskustvo u pisanju o složenima i osjetljivim temama kakvo se kod autora starijih generacija s prostora bivše države ne susreće često. Čak i kada tematizira najosjetljivije aspekte neoosmanizma, pa i one koji su mu najbliži srcu, a to je utjecaj turske politike na područje Balkana i Srbije, autora ne vode emocije nego znanstvena odmjerenost. Tanasković suvereno vlada temom pa je tekst istodobno opušten i lucidan, nikad radikalan, pompozan ili provokativan. No ne treba dvojiti o tome da knjiga ima "misiju". Zapadni će čitatelj iz nje iščitati poruku kako je neoosmanizam ozbiljna prijetnja ionako krhkoj stabilnosti Balkana, a potom i drugih krajeva prema kojima se usmjerava, pa i same Europe. Čitatelju s područja kojima je Osmansko Carstvo nekoć vladalo i kojega na postojanje te prijetnje upozorava generacijski instinkt za preživljavanjem, poruka je da neuke predrasude nisu način suočavanja s njome.

Boris Havel 